\title{
ANALYZING INFLUENCE OF ELECTRONIC WORD OF MOUTH (EWOM) TOWARDS VISIT INTENTION WITH DESTINATION IMAGE AS MEDIATING VARIABLE: A STUDY ON DOMESTIC VISITORS OF MUSEUM ANGKUT IN BATU, INDONESIA
}

\author{
Kusumawati Andriani ${ }^{*}$, Aprilia Fitri, Abdillah Yusri \\ University of Brawijaya, Indonesia \\ *E-mail: andriani kusuma@ub.ac.id
}

\begin{abstract}
Objective of this study is to analyze and explain how much influence Electronic Word of Mouth (eWOM) has towards visit intention with destination image as mediating variable. The study was categorized as explanatory research. The sampling method was purposive sampling. The population is domestic visitors of Museum Angkut while the respondents were 160 domestic visitors of the tourist visitors. The analysis method was path analysis. The findings stated that eWOM has a positive and significant influence towards visit intention directly. In addition, eWOM has influenced towards visit intention through destination image, the mediating variable. EWOM also has significant influence towards destination image. Finally, destination image has a positive and significant influence towards visit intention.
\end{abstract}

\section{KEY WORDS}

Electronic word of mouth, destination image, visit intention, public service.

Rapid growth of interactive tourism brings some advantages to certain groups of individuals (Pujiastuti, et al., 2017). Tourism creates job opportunity and helps community members develop their career through retail business, construction, manufacturing industry, telecommunication and tourist agency (Mohamad, et.al., 2014). Recently, tourism is considered as one of the world's largest industry because it generates significant amount of revenue for a country (Pangestuti, 2017). Tourism has strategic roles in creating job vacancy and generating foreign exchange. Furthermore, development of information technology has encouraged researchers to conduct academic studies that discuss tourism.

Growth of information technology has generated a new terminology, namely electronic Word of Mouth (eWOM), a new paradigm in Word of Mouth communication. EWOM can reach a wider market compared to conventional advertisement. Information technology, scope and prospectus of WOM have increased exponentially. Type of exchange of knowledge on online and public platform is called Electronic Word of Mouth (eWOM) (Charo et al., 2015).

Many considered eWOM as evolution from traditional-interpersonal communication to cyberspace; information technology allows customers to find as much information as they need before making purchase (Semuel and Lianto, 2014). Using eWOM, actual, potential or previous customers can leave either positive or negative opinion about product or company, in which the information is accessible for everyone or any institution via internet (Thurau et al., 2004).

EWOM can affect tourist decision to buy a product, for example attract visitors to certain tourist attraction. EWOM promotes certain tourist attraction more effectively describing positive image of the tourist destination and previous visitors' opinion about the tourist destination. EWOM improves destination image of a tourist attraction and increases customer satisfaction and loyalty. Frequent and positive WOM, one coming from satisfied visitors, is a reliable indicator of customer's satisfaction and loyalty (Setiawan et.al, 2014).

Internet and social media such as Instagram, Facebook, Twitter, and Blog facilitate eWOM. EWOM, either positive or negative, helps developing destination image. Empirical studies show that online review has significant influence towards destination image (Govers and Go, 2004; Mridula, 2009). As an addition, Suwarduki, et.al (2016), and Wang (2015) reported that destination image has significant influence towards visit intention. 
Visit intention, according to Hsu and Huang (2010) and Lam and Hsu (2006), can be discussed based on Theory of Planned Behavior (TPB). Lam and Hsu (2006) showed that past behavior, subjective norm and controlled behavior have direct influence towards visit intention. However, Hsu and Huang (2010) argued that construction of TPB predicting interest may not always be manifested as actual behavior.

This combined the findings of the previous related studies and applied them to service industry, namely domestic visitor of Museum Angkut, a prominent tourist destination in Batu. Museum Angkut is one of the icons of educational tourism in Indonesia because it is the largest transportation museum in Indonesia. Museum Angkut is a modern museum that transforms the role of museums into center for preservation, research and communication and aims to provide function as channel of education and means of recreations for the society (Weil, 1990; Hooper-Greenhill, 1994).

The fact shows that activities in museum have developed due to change of paradigm. Activities in museum was once closely associated to collection of artifacts, but recently, the activities has become more public-oriented. Museum is no longer considered as a place to store rare and expensive artifacts; instead it is a cultural institution that serves the society (Magetsari, 2008). Therefore, museum has started developing as an institution more welcoming for the public (Pamuji, 2011).

Besides that, Urry (1998) stated that postmodern museum has developed recently, in which visitors can take active participation in an exhibition instead of passively standing while observing the exhibition. In other words, postmodern museum treats artifacts and exhibition as means of entertainment. Postmodern museum combines education and entertainment through either an open or closed museum or other recreational facilities.

Tourism sector has pretty significant market potential and profit margin, but at the same time, the sector opens widely for everyone and consequently competition between actors in this sector can be rather cut-throat. Actors in the sector compete against one another to promote their tourist package. As the result, potential visitors have a lot of options prior to selecting which tourist destination they are going to visit. On the other hand, rapid development of accessible information and technology has positive impact towards marketing sector.

In accordance to the elaboration, Urry (1998) stated that many times visitors select tourist destination based on their imagination or fantasy or image of the destination. The fantasy and image are created and developed based on not only tourist-related activities (promotion), but also non tourist-related activities, such as academic work, academic fora (seminar and workshop) and mass media.

Internet and social media will impact eWOM and many believe that combination of these two can function as marketing communication strategy that influences destination image and visit intention of other people. Based on the elaboration, the researchers are interested in conducting a study entitled "Analysis on Influence of Electronic Word of Mouth (eWOM) towards Visit intention with Destination Image as Mediating variable (A Study on Domestic Visitors of Museum Angkut)".

Based on the background, statements of problems in the study are as follows:

- Does eWOM have significant influence towards destination image?

- Does eWOM have significant influence towards visit intention?

- Does destination image have significant influence towards visit intention?

\section{LITERATURE REVIEW}

EWOM is defined as positive or negative statement of potential, actual and previous customers about a product or company made accessible to wider audience through the internet (Thurau et al., 2004). Through the internet, ideas and opinions of an individual are more accessible for other internet users (Dellarocas, 2003). Internet users write reviews on tourist destination, hotels and tourist agencies and these reviews have become important sources of information for prospective tourists (Pan, et.al, 2007). Reports show that every year hundreds of millions of prospective visitors use online reviews as reference prior to 
going on vacation (Tripadvisor.com, 2011). 84\% of the visitors use online reviews as reference when making their travel reservation (Travelindustrywire.com, 2007).

Goldenberg, et.al (2001) emphasized that tourist decision-making is strongly influenced by WOM from other tourists. Gretzel and Yoo (2008) reported that readers often considered reviews provided by other travelers more up-to-date, interesting and reliable compared to nformation from travel agency. EWOM is considered as an important source of information that influences visit intention and choices of destination (Yun and Good, 2007; Soderlund and Rosengren, 2007; Jalilvand and Samiei, 2012). Furthermore, Vermeulen and Seegers (2009) mentioned that positive online reviews increase perception about hotels among potential tourists.

UNWTO (2007) defined destination as places tourists visit and the visit can influence other's decision to travel. Therefore, tourist destination represents final destination for tourism (Leiper 1979). Tourist destination, place, region or country, is the main reason for and end product of tourism. It also includes special places different from ordinary location due to culture, history, archeology or nature (Urry \& Rojek 1997). Berman (2005) defined destination as a country, state, region, area or city that is marketed or markets itself as a place for tourists to visit.

Echtner and Ritchie (1991) defined destination image as multidimensional concept that consists of symbolic and tangible features. As an addition, Baloglu and McCleary (1999) defined destination image as qualified experience, attraction, value/environment, relaxation/getaway, awe/adventure, knowledge, social aspect and prestige. According to Lopes (2011), even though an individual has yet to visit one place, he or she can have destination image about the place in their head based on information they can access. Destination image is mental representation of attractive places (Lawson and Baud-Bovy, 1977; Fakeye and Crompton, 1991; Bigne et al., 2001).

Wang et al., (2015) stated that visit intention refers to possibility to visit particular places in certain period. Some behavioral theories investigated how motivational factors help developing visitor's behavior and how the phenomenon leads to visit intention (Lam \& Hsu, 2004, 2006; March \& Woodside, 2005a).

One frequently discussed aspect of consumer behavior is Theory of Planned Behavior (TPB) (Ajzen, 1991). TPB treats both as social (namely subjective norm) and psychology (namely attitude), factors in developing consumer behavior and have neem widely accepted and implemented to predict individual behavior in hotel booking (Buttle \& Bok, 1996), selecting destination (Lam \& Hsu, 2006), and social psychological studies (Conner, et.al, 2001). TPB is derived from assumption that human is rational being and uses information systematically. Prior to decision-making, individuals run analysis on implication of their actions. Based on the empirical studies, the hypotheses are as follows:

H1: eWOM $(X)$ has significant influence towards destination image (Y1).

A number of previous studies suggested that eWOM has positive influence towards destination image. Jalilvand and Samiei (2012) investigated the influence of eWOM towards brand image and purchase intention in car industry in Iran. EWOM was the independent variable in the study. The findings stated that eWOM has positive influence towards destination image.

In addition, Charo, et.al (2015) also conducted a study to analyze influence of eWOM in brand image and purchase intention towards adoption of on-line opinions. The indicators were argument quality, source credibility, adoption and usefulness of information, eWOM among customer, brand image and purchase intention. Based on the findings of the study, eWOM can potentially influence brand image and it influenced message recipients' perception about goods or service.

The findings of these studies indicated that eWOM has influence towards destination image. Even though they focused on products, these research provides empirical evidence to develop similar study in another sector, namely tourist destination.

H2: eWOM $(X)$ has significant influence towards visit intention (Y2).

Previous related studies reported that eWOM has positive influence towards visit intention. Jalilvand, et.al (2013) stated that eWOM has significant influence towards attitude 
towards a tourist destination and visit intention. Jalilvand and Samiei (2012) developed a model describing influence of eWOM with purchasing intention such as brand image as partial mediating variable. Jalilvand and Samiei (2012) also reported similar findings, that brand image is a full mediating variable of purchasing intention.

Penelitian ini juga sejalan dengan Fan and Miao (2012) yang meneliti pengaruh dari eWOM terhadap minat pembelian dari wisatawan di Taiwan and menghasilkan temuan bahwa hubungan positif ditegaskan. Hasil penelitian menunjukkan kredibilitas eWOM yang dirasakan memiliki pengaruh signifikan pada penerimaan eWOM and minat untuk membeli. Hasil penelitian menunjukkan bahwa penelitian ilmu sosial berbasis gender dapat diterapkan untuk komunitas virtual and transaksi e-commerce.

The findings of the studies suggested that eWOM has influence towards visit intention. EWOM can have direct influence towards purchasing or visit intention or indirect influence through several mediating variables, such as brand or destination image.

H3: Destination image (Y1) has significant influence towards visit intention (Y2).

Some previous related studies suggested that destination image has positive influence towards visit intention. Chalip, et.al (2003) reported that destination image has significant influence towards intention to visit particular destination. Bigne, et.al (2005) argue that there is a positive relationship between destination image of the whole community and intention to give recommendation for tourists to visit their place.

Moreover, Jalilvand and Samiei (2012) found out that destination image has significant influence towards visit intention. Based on the study, $45 \%$ of the respondents used their emails for eWOM, $40 \%$ relied upon their company websites and $30 \%$ used other media (for example facebook.com) for eWOM. It means in Iran most customers use email to spread eWOM. Unlike those in Iran, based on the data from "Asosiasi Penyelenggara Jaringan Internet Indonesia" (APJII) or Indonesian Association of Internet Network Provider, most Indonesian consumers use social media, for instance Facebook, Instagram, and Twiter, to access information about eWOM.

The studies indicated that destination image has influence towards visit intention. In this study, destination image is a mediating variable connecting eWOM and visit intention. The study also investigated both direct and indirect influence of eWOM on visit intention with destination image as mediating variable.

The study evaluated relationship between eWOM, destination image and visit intention. Based on the background, literature review and previous related studies, the following chart described the conceptual framework of the study.

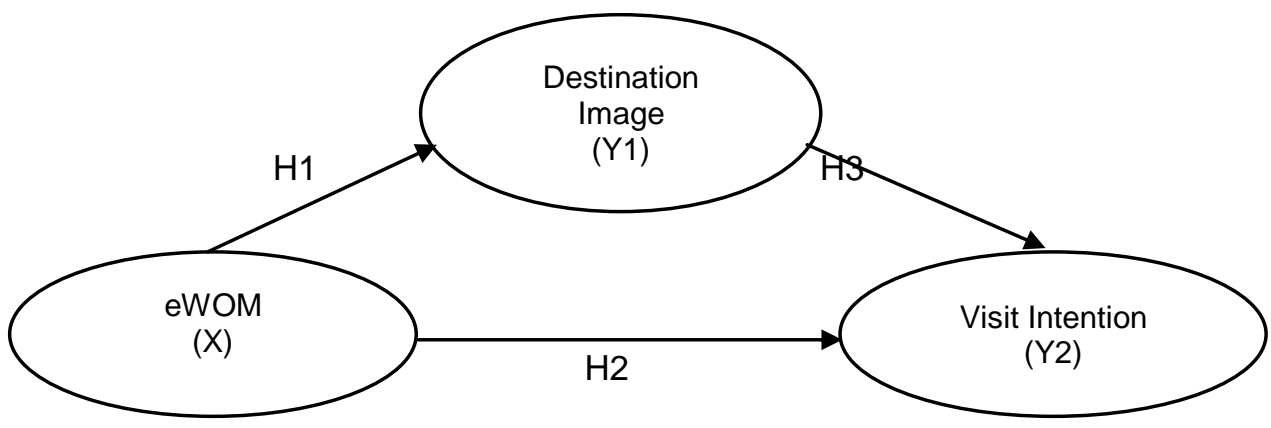

Figure 1 - Conceptual Framework (Source: Researchers, 2018)

\section{METHODS OF RESEARCH}

The study can be categorized as explanatory research because it aims to explain generalization of samples towards population or explain relationship, differences or influence of one variable towards another variable; thus, this type of research involves sample and hypothesis. The study used quantitative approach through analytical thought pattern. The study was conducted to tourists visiting Museum Angkut Kota Batu based on information 
they obtained through eWOM. The population was 17-year-old or older domestic tourists who visited Museum Angkut Kota Batu based on eWOM from other visitors. The criteria used to select the population were as follows:

- Museum Angkut domestic visitor whose age is 17 years old and older;

- Domestic visitors who visit Museum Angkut for the first time;

- Domestic visitors who obtain information about Museum Angkut on social media (Facebook, Instagram, Website and others).

The sampling method was purposive sampling and based on the Machin and Champbell's formula, the total respondents were 160 respondents. The data collection was questionnaire distribution. The questionnaires were distributed offline in order to obtain respondents that meet the criteria. The samples were collected on the weekends between April and May, 2018. In addition, the researchers also had some time to have interaction with the respondents to probe more detail information from the respondents. The analysis technique was path analysis with the help of SPSS (Statistical Package for Social Science) software.

\section{RESULTS OF STUDY}

H1: eWOM $(X)$ has significant influence towards destination image (Y1). The analysis showed that eWOM has positive and significant influence towards destination image. The coefficient was 0.511 , t-value was 7.152 and significance was $0.000(<0.05)$. The findings are in line with Ishida, et.al, (2016) and Wang (2015). Both studies showed that eWOM has positive and significant influence towards destination image. Other evidence was average score of eWOM (4.43) and the highest indicator (4.47). It means eWOM resulted in an increase in destination image; reading online review on a tourist destination encouraged visitors to visit the destination.

In addition, the respondents actively seek information about tourist destination on social media. $55.63 \%$ of the respondents looked for information about Museum Angkut from web browser, $24.38 \%$ from Instagram and $8.75 \%$ from Facebook. The findings are in accordance to Bowie and Buttle (2004)'s statement in their book entitled Hospitality Marketing that integration of technology in tourism sector is closely related to innovation and growth of ICT. Therefore, Museum Angkut should improve their social media platform to increase destination image.

H2: eWOM $(X)$ has significant influence towards visit intention (Y2). The analysis showed that eWOM has positive and significant influence towards visit intention. The coefficient was 0.288 , t-value was 7.256 and significance was $0.000(<0.05)$. It is in line with Jalilvand, et.al (2013) that eWOM has significant influence towards attitude to visit and visit intention. It is also in accordance to Wang (2015) that eWOM has positive and significant influence towards visit intention.

Another evidence was most of the respondents (24.36\%) are between 21 and 25 years old. Known as millennial generation, they are techno-savvy and use social media frequently.

They have fear of missing trends and therefore, try keep up with the most current trend. The majority of the respondents (43.13\%) visited Museum Angkut having seen other people's status update on social media sosial, either Instagram, facebook, whastapp or web browser. 33\% visited the tourist destination because they wanted to visit a new tourist destination, one they had never visited before. 16.25\% visited Museum Angkut because it is unique and $7.50 \%$ visited the place to boost their prestige.

H3: Destination image (Y1) has significant influence towards visit intention (Y2). The analysis showed that destination image has positive and significant influence towards visit intention. The coefficient was 0.270 , t-value was 6.943 and significance was $0.000(<0.05)$. The findings are in accordance to Chalip, et al., (2003); Bigne, et al., (2005); Jalilvand, et.al., (2012); Wang (2015); and Pujiastuti et al (2017) reporting that destination image has positive and significant influence towards visit intention.

Unique and different concepts Museum Angkut offers are two aspects attracting visitors. The concepts match those of destination image, a destination different from other 
due to its culture, history, archeology or nature (Urry \& Rojek 1997). Another relevant information was the frequency of destination image (4.30), which means that the respondents had positive attitude towards Museum Angkot. Museum Angkut offers unique and novel concept was the item with the highest loading factor which indicated that good destination image will increase visit intention.

\section{CONCLUSION}

Based on the result of the data analysis, the findings and hypothesis-testing, it can be concluded that:

- eWOM has positive and significant influence towards destination image. The path analysis showed that the significance was 0.000 and coefficient was 0.511 ;

- eWOM has positive and significant influence towards visit intention. The path analysis showed that the significance was 0.000 and coefficient was 0.288 ;

- Destination image has positive and significant influence towards visit intention. The path analysis showed that the significance was 0.000 and coefficient was 0.270 .

Based on the conclusion, it is recommended that:

1. Future researchers should conduct similar study discussing various objects and characteristics of respondents in order to obtain more comprehensive findings;

2. Local government can use the findings to design and establish policy on tourist management and tourist development;

3. Jatim Park Group, one responsible for Museum Angkut, can use the findings as reference for improving their social media platform and promotion.

\section{REFERENCES}

1. Abubakar, M. A., Mustafa, I., Raad, M. A., \& Kayode, K. E. (2017). eWOM, revisit intention, destination trust and gender. Journal of Hospitality and Tourism Management, 31, 220-227.

2. Abubakar, M. A., \& Mustafa, I. (2015). Impact of online WOM on destination trust and intention to travel: A medical tourism perspective. Journal of Destination Marketing \& Management, 5(3), 192-201.

3. Ajzen, I. (1991). The theory of planned behavior. Organizational Behavior and Human Decision Processes, 50(2), 179-211

4. Baloglu, S., \& McCleary, K. W. (1999). US international pleasure travellers' image of four Mediterranean destinations: a comparison of visitors and nonvisitors. Journal of Travel Research, 38(2), 114-129.

5. Becerra., \& Korgaonkar. (2011). Effects of trust beliefs on consumers' online intention. Journal of Marketing, 45(6), 936-962.

6. Berman, B. (2005). How to delight your customers. California Management Review, 48(1), 129-151.

7. Bigne, E., Sanchez, M. I., \& Sanchez, J. (2001). 'Tourism image, evaluation variables and after purcahse behaviour: inter-relationship. Tourism Management, 22(6), 607-616.

8. Bigne, E., Sanchez., Isabel, S. G., \& Silvia, S. B. (2005). Relationships among residents' image, evaluation of the stay and post-purchase behaviour. Journal of Vacation Marketing, 11(4), 291.

9. Bowie, D., \& Francis, B. (2004). Hospitality Marketing: An Introduction. London: Elsevier Butterworth Heinemann.

10. Buttle, F. A. (1998). Word of mouth: Understanding and managing re-ferral marketing. Journal of Strategic Marketing, 6, 241-254.

11. Buttle, F., Bok, B. (1996). Hotel marketing strategy and the theory of reasoned action. International Journal of Contemporary Hospitality Management, 8(3), 5-10.

12. Chalip, L., Christine, B. G., \& Brad, H. (2003). Effects of Sport Event Media on Destination Image and Intention to Visit. Journal of Sport Management, 17(3), 214-234. 
13. Charo, N., Pershant, S., Saadullah, S., Abdul, H., \& Muhammad, Z. S. (2015). Determining The Impact Of E-Wom on Brand Image And Purchase Intention Through Adoption Of Online Opinions. International Journal Of Humanities And Management Sciences, 3(1).

14. Conner, M., Kirk, S. F., Cade, J. E., \& Barrett, J. H. (2001). Why do women use dietary supplements? The use of the theory of planned behavior to explore beliefs about their use. Social Science and Medicine, 52(4), 621-633.

15. Dellarocas, C. (2003). The digitization of word of mouth: promise and challenges of online feedback mechanisms. Management Science, 49(10), 14-24.

16. Echtner, C. M., \& Ritchie, J. R. B. (1991). The meaning and measurement of destination image. The Journal of Tourism Studies, 2(2), 2-12.

17. Fakeye, P. C., \& Crompton, J. L. (1991). Image differences between prospectives, firsttime and repeat visitors to the lower Rio Grande valley. Journal of Travel Research, 30(2), 10-16.

18. Goldenberg, J., Libai, B., * Muller, E. (2001). Talk of the network: A complex systems look at the underlying process of word-of-mouth. Marketing Letters, 12(3), 211-223.

19. Govers, R., \& Go, F. M. (2004). Projected destination image online: Website content analysis of pictures and text. Information Technology and Tourism, 7(2), 73-89.

20. Gretzel, U., \& Yoo, K. (2008). Use and impact of online travel reviews. Information and communication technologies in tourism. New York: Springer-Verlag.

21. Hooper-Greenhill, E. (1994). The Educational Role of the Museum (2 $\left.{ }^{\text {nd }} E d\right)$. London: Routledge.

22. Hsu, C. H. C., \& Songshan, S. H. (2010). Formation of Tourist Behavioral Intention and Actual Behavior. International Conference Service Systems and Service Management (ICSSSM).

23. Ishida, K., Lisa, S., \& Katia, S. (2016). The Effects of Traditional and Electronic Word-ofMouth on Destination Image: A Case of Vacation Tourists Visiting Branson, Missouri. Administrative Science, 6(4), 1-17.

24. Jalilvand, M. R., Neda, S., Behrooz, D., \& Parisa, Y. M. (2012). Examining the structural relationships of electronic word of mouth, destination image, tourist attitude toward destination and travel intention: An integrated approach. Journal of Destination Marketing \& Management, 1(1-2), 134-143.

25. Jalilvand, M. R., Abolghasem, E., \& Neda, S. (2013). Electronic Word of Mouth Effects on Tourist's Attitudes Toward Islamic Destinations and Travel Intention: an Empirical Study in Iran. Procedia - Social and Behavioral Sciences, 81, 484 - 489.

26. Jalilvand, M. R., \& Neda, S. (2012). The effect of electronic word of mouth on brand image and purchase intention An empirical study in the automobile industry in Iran. Marketing Intelligence \& Planning, 30(4), 460-476.

27. Jalilvand, M. R., \& Neda, S. (2012). The effect of word of mouth on inbound tourists' decision for traveling to Islamic destinations (the case of Isfahan as a tourist destination in Iran). Journal of Islamic Marketing, 3(1), 2-21.

28. Lam, T., Catty, H. C., \& Hsu. (2006). Predicting behavioral intention of choosing a travel destination. Tourism Management, 27(4), 589-599.

29. Lawson, F., \& Baud-Bovy, M. (1977). Tourism and Recreational Development. London: Architectural Press.

30. Leiper, N. (1979). The framework of tourism. Annals of Tourism Research, 10, 390-407.

31. Lopes, S. D. F. (2011). Destination image: origins, developments and implications. PASOS Revista de Turismo y Ptrimonio Cultural, 9(2), 305-315.

32. Magetsari, N. (2008). Filsafat Museologi. Museografia, II(2), 5-15

33. Mohamad, M., Nur, I. A. G., Mustafa, M., \& Ibrahim, M. 2014. Satisfaction as a Mediator to the Relationships Between Destination Image and Loyalty. World Applied Sciences Journal, 30(9), 1113-1123.

34. Mridula, D. (2009). Online destination image of India: A consumer based perspective. International Journal of Contemporary Hospitality Management, 21(2), 226-232. 
35. Pangestuti, E. (2017). Analisis Daya Saing Dengan Menggunakan Destination Competitiveness Model (Studi Pada Heritage Tourism Di Jawa). E-Journal Fakultas IImu Admnistrasi Universitas Brawijaya, 11(1).

36. Pujiastuti, E. E., Umar, N., Suharyono., \& Andriani, K. (2017). The Antecedents Of Behavioral Intention Regarding Rural Tourism Destination. Asia Pacific Journal of Tourism Research, 22(11), 1169-1181.

37. Pujiastuti, E. E., Umar, N., Suharyono., \& Andriani, K. (2017). Study On Destination Image, Satisfaction, Trust And Behavioral Intention. Russian Journal of Agricultural and Socio-Economic Sciences, 1(61).

38. Semuel, H., \& Adi, S. L. (2016). Analisis eWOM, Brand Image, Brand Trust And Minat Beli Produk Smartphone Di Surabaya. Jurnal Manajemen Pemasaran, 8(2), 7-54.

39. Soderlund, M., \& Rosengren, S. (2007). Receiving word-of-mouth from the service customer: An emotion-based effectiveness assessment. Journal of Retailing and Consumer Services, 14(2), 123-136.

40. Suwarduki, P. R., Edy, Y., Kholid, M. M. (2016). Pengaruh Electronic Word Of Mouth Terhadap Destination image Serta Dampaknya Pada Minat And Keputusan Berkunjung (Survei Pada Followers Aktif Akun Instagram Indtravel Yang Telah Mengunjungi Destinasi Wisata Di Indonesia). E-Journal Fakultas Ilmu Admnistrasi Universitas Brawijaya, 37(2).

41. Thurau, T. H., \& Gianfranco, W. (2004). Word of mouth: Motives for and consequences of reading customer articulations on the internet. International Journal of Electronic Commerce, 8(2), 51-74.

42. Travelindustrywire.com. (2007). Travel reviews-Consumers are changing your brand and reputation online. Retrieved from /http://www.travelindustrywire.com/arti cle29359.

43. UNWTO. (2007). A practical Guide to Tourism Destination Management. Madrid: World Tourism Organization.

44. Urry, J. (1998). The Tourist Gaze: Leisure and Travel in Contemporary Societies. London: SAGE Publication.

45. Vermeulen, I. E., \& Daphne, S. (2009). Tried and tested: The impact of online hotel reviews on consumer consideration. Tourism Management, 30 (1), 123-127.

46. Wang, Y. C. (2015). A study on the influence of electronic word of mouth and the image of gastronomy tourism on the intentions of tourists visiting Macau. Tourism, 63(1), 67-80.

47. Weil, S. E. (1990). Rethinking the Museum and Other Meditations. Washington DC: Smithsonian Institution Scholarly Press.

48. Yun, Z. S., \& Good, L. K. (2007). Developing customer loyalty from e-tail store image attributes. Managing Service Quality, 17(1), 4-22. 